\title{
Agro-Economic Benefits of Weed Biomass and Crop Residue in Maize Production Systems in Coastal Kenya
}

\author{
Saha, H.M. \\ Pwani University, Department of Crop Sciences, P.O. Box 195 - 80108 Kilifi, Kenya
}

\begin{abstract}
The climatic conditions of coastal Kenya favour rapid weed growth, leading to the accumulation of large biomass of weeds between cropping seasons. Smallholder farmers in the region usually slash and remove the weed biomass and crop residue from their farms during land preparation in order to facilitate easy planting. The impact of such practice on the production of maize has not been assessed. The aim of this study was to determine the effect of the farmers' practice on the performance of maize and fertilizer requirement. Three methods of managing weed biomass and crop residue (removal from field, incorporation into soil, or use as

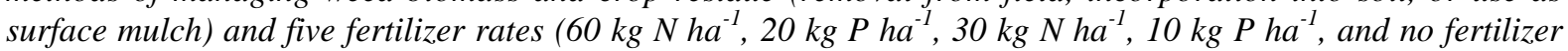
application) were evaluated. Removal of weed biomass and crop residue from the field led to 20-26\% loss in grain yield and reduced the returns to labour by 41-51\%.There was no response to applied $P$ where weed biomass and crop residue had been incorporated into soil. Efforts should therefore be made to educate farmers on the advantages of retaining weed biomass and crop residue on their farms as they prepare land for subsequent crops.
\end{abstract}

Keywords: Weed biomass, crop residue, maize yield, fertilizer requirement

\section{Introduction}

Majority of the smallholder farmers in coastal lowland Kenya are faced with the problem of low agricultural productivity. The average on-farm maize grain yield in coastal lowland Kenya is 1-1.5 t ha ${ }^{-1}$ (Wekesa et al., 2003). This is too low to sustain the annual food requirement of an average household, estimated at $2.7 \mathrm{t}$ maize grain for a ten-member family (H.M. Saha, Unpublished data). The maize yield of $1.0-1.5 \mathrm{t} \mathrm{ha}^{-1}$ is only 19-28\% of the potential yield for coastal lowland Kenya (Saha et al., 2008). Low soil fertility has been identified as a major factor contributing to the low maize yields (Saha et al., 2008).

Nitrogen deficiency is known to be a major yield-limiting factor in the world, making fertilizer $\mathrm{N}$ application an essential input for crop production in most agricultural systems (Spiertz, 2010). However, over $90 \%$ of coastal farmers cannot afford the use of inorganic fertilizers to restore soil fertility because of their low household incomes (Mureithi et al., 2000). The few farmers who use inorganic fertilizers apply them at suboptimal rates (Omamo et al., 2004) because they cannot afford the recommended rates. The farmers' economic limitation has also led to the reliance on the hand hoe for land preparation. Due to the slow and drudgery nature of land preparation by hand, it is quite common to find farmers planting late into the rainfall season, leading to inadequate utilization of the rains by crops. Only a few of the smallholder farmers hire tractors to prepare land, at a cost of KES $6,250 \mathrm{ha}^{-1}$.

High ambient temperatures of $30^{\circ} \mathrm{C}$ and $80 \%$ relative humidity favour rapid weed growth in coastal Kenya, leading to the accumulation of large weed biomass between cropping seasons (Saha, 2015). Weeds and crop residue found on farms at the onset of a cropping season are good organic resources since some could be used as fodder for livestock or incorporated into soil during land preparation for the benefit of a subsequent crop. Organic materials are known to influence nutrient availability to crops by releasing nutrients into the soil during their decomposition, acting as energy sources for microbial activities, and reducing $\mathrm{P}$ sorption of soil (Palm et al., 1997). Weed biomass and crop residue therefore have potential to improve soil fertility if allowed to decompose and release nutrients back into soil.

In addition to their contribution to nutrient supply upon their subsequent decomposition, weed plants take up nitrogen during growth and prevent its loss through leaching. Despite the said positive contributions by weed plants, smallholder farmers in coastal lowland Kenya usually consider them and crop residue a nuisance during land preparation and therefore slash and remove them from their farms. The effect of removing plant material from farms before tilling has not been documented for the hot-humid region of Kenya. The objective of this study was to determine the effect of improved management of weed biomass and crop residue that accumulate on farms between cropping seasons on the performance of maize and the requirement for fertilizer input. 


\section{Materials and Methods}

The study was conducted in coastal lowland Kenya, located at latitude $3.93^{\circ}$ South and longitude $39.73^{\circ}$ East. The soils at the study site are sandy, have very low organic carbon content $\left(3.3 \mathrm{~g} \mathrm{~kg}^{-1}\right)$, are deficient in nitrogen $\left(0.6 \mathrm{~g} \mathrm{~N} \mathrm{~kg}^{-1}\right)$ and are prone to leaching (Saha, 2015). Based on the guidelines outlined by Okalebo et al. (2002), the extractable $P$ content of the soil $\left(17.5 \mathrm{mg} \mathrm{kg}^{-1}\right)$ is slightly above the critical level $\left(10 \mathrm{mg} \mathrm{kg}^{-1}\right)$ below which crop responses to phosphate fertilizers should be expected. The treatments consisted of factorial combinations of three methods of managing weed biomass and crop residue in the field during land preparation (removed from field, incorporated into soil, or used as surface mulch) and five fertilizer rates (60 kg N ha ${ }^{-1}, 30$ $\mathrm{kg} \mathrm{N} \mathrm{ha}{ }^{-1}, 20 \mathrm{~kg} \mathrm{P} \mathrm{ha}^{-1}, 10 \mathrm{~kg} \mathrm{P} \mathrm{ha}^{-1}$, and no fertilizer application). Before land preparation, representative samples of weed biomass (consisting of multiple species) were collected from the experimental field and prepared for laboratory analysis to determine their nutrient content. Land preparation was done using a hand hoe. A randomized complete block design (RCBD) was used, and the treatments were replicated four times. The experimental plots were weeded twice, at 3 and 7 weeks after maize emergence. Bulldock $(0.05 \mathrm{GR} 0.5 \mathrm{~g} / \mathrm{kg}$ Beta cyfluthrin) was applied immediately after each weeding in order to control the stem borer. Data was collected on labour usage for managing weed biomass and crop residue, weight of maize ears, and grain moisture content. All data were subjected to the analysis of variance (ANOVA) using the PROC GLM procedure of the Statistical Analysis System (SAS Institute, 1999). Mean separations were done using the least significant difference (LSD) at the $5 \%$ level of significance. Returns to investment in labour for managing weed biomass and crop residue were calculated using the following equation 1 :

$$
R_{l}=\frac{Y \times P_{m}}{L \times C_{l}}
$$

where $\mathrm{R}_{1}=$ returns to labour, $\mathrm{Y}=$ maize grain yield in $\mathrm{tha}^{-1}, \mathrm{P}_{\mathrm{m}}=$ price per ton of maize grain, $\mathrm{L}=$ number of person-days of labour per hectare, and $\mathrm{C}_{1}=$ cost per person-day.

Returns to investment in fertilizer nutrient were calculated using the following equation 2 :

$$
R_{n}=\frac{Y_{\Delta} x P_{m}}{A_{r} x P_{n}}
$$

where $R_{n}=$ returns to fertilizer nutrient, $Y_{\Delta}=$ corresponding yield increase in $t \mathrm{ha}^{-1}, \mathrm{P}_{\mathrm{m}}=$ price per ton of maize grain, $A_{r}=$ nutrient application rate, and $P_{n}=$ equivalent unit price of nutrient.

Returns to total investment in fertilizer nutrient and/or labour for managing weed biomass and crop residue were calculated using the following equation 3 :

$$
R_{n l}=\frac{Y_{\Delta} x P_{m}}{L x C_{l}+C_{n}}
$$

where $R_{n l}=$ returns to investment in fertilizer nutrient and/or labour, $Y_{\Delta}=$ corresponding yield increase in $t \mathrm{ha}^{-1}$, $\mathrm{P}_{\mathrm{m}}=$ price per ton of maize grain, $\mathrm{L}=$ corresponding labour in person-days, $\mathrm{C}_{1}=$ cost per person-day of labour, and $\mathrm{C}_{\mathrm{n}}=$ cost of nutrient.

\section{Results and Discussion}

Gathering and carrying plant material to the edges of the field and then tilling the soil, as practiced by smallholder farmers in coastal Kenya, took $26 \%$ more time (63 person days) than that required for incorporating the material into soil (50 person days) (Table 1). This led to lower returns to labour (KES 5.6) compared to that realized with incorporation of weed biomass and crop residue (KES 9.5). Land preparation without incorporation of weed biomass and crop residue (i.e. with material left on the surface as mulch) took $24 \%$ less time (38 person days) and gave higher returns to labour (KES 11.5) than realized with the digging-in of plant material into soil.

Method of managing the weed biomass and crop residue at the time of land preparation had significant effect $(\mathrm{P}<0.05)$ on maize grain yield. Removal of weed biomass and crop residue from the field, other than leaving the material on the soil surface as mulch or incorporating it into the soil, led to $20-26 \%$ loss in maize grain yield (i.e. a loss of 0.7-1.0 $\mathrm{t} \mathrm{ha}^{-1}$ ), respectively. This reflects a loss of 720-990 kg of maize grain per 
hectare per cropping season, enough to feed one adult person for about three years or a family of 10 persons for about 3-4 months, respectively. In addition to the loss in crop yield, residue removal has been shown to have negative effects on soil chemical and physical properties. In a study conducted in the USA, repeated complete removal of residue caused significant increase in bulk density as well as decrease in soil aggregation and total organic carbon (Al-Kaisi and Guzman, 2012). On average, retention of weed biomass and crop residue on the farm increased maize grain yield by a factor of 1.31. This yield gain is similar to that reported by Pandiaraj et al. (2015) for wheat grown following crop residue incorporation. These results show that farmers would make significant yield gains and, hence, improve their household food situation through adequate utilization of the weed biomass and crop residue in the fields at the time of land preparation.

Table 1: Effect of method of managing weed biomass and crop residue during land preparation on maize grain yield

\begin{tabular}{|l|c|c|c|}
\hline $\begin{array}{l}\text { Method of managing weed } \\
\text { biomass and crop residue }\end{array}$ & $\begin{array}{l}\text { Grain yield } \\
\left(\mathrm{t} \mathrm{ha}^{\dagger}\right)\end{array}$ & $\begin{array}{l}\text { Labour used }^{\S} \\
\left(\text { person days ha }^{-1)}\right.\end{array}$ & $\begin{array}{l}\text { Returns (KES) per KES } \\
\text { spent on labour }\end{array}$ \\
\hline Incorporation & $3.8^{\mathrm{a}}$ & 50 & 9.5 \\
\hline Mulching & $3.5^{\mathrm{a}}$ & 38 & 11.5 \\
\hline Removal from field & $2.8^{\mathrm{b}}$ & 63 & 5.6 \\
\hline LSD $_{0.05}$ & 0.31 & & \\
\hline
\end{tabular}

${ }^{\dagger}$ Maize costs KES 25,000 per metric ton; $§$ Labour costs KES 200 per person-day. "Person-day" is equivalent to 8-hours work of an adult person per day in the field. Grain yield means followed by the same letter are not significantly different $(\mathrm{P}<0.05)$.

In addition to the yield gains realized with improved management of weed biomass and crop residue during land preparation, farmers would increase the returns to their labour by abandoning the current practice of removing all plant material from the field before tilling their land. The labour requirements for the three methods of managing weed biomass and crop residue were higher than those reported by Mureithi et al. (2002) for managing legume residues in Central Kenya. The difference in the observed requirements for labour is probably because of the relatively large bulk of plant material handled by farmers in coastal Kenya, resulting from the rapid weed growth favored by the warmer conditions in the region than those for Central Kenya.The results further showed that application of nitrogen at rates of 30 and $60 \mathrm{~kg} \mathrm{~N}^{-1}$ led to 43 and $57 \%$ increase in maize grain yield, respectively, above the yields realized from unfertilized maize (Table 2). The maize response to nitrogen applied at a rate as low as $30 \mathrm{~kg} \mathrm{~N} \mathrm{ha}^{-1}$ (half the nitrogen application rate recommended for the region) confirms that soils in coastal Kenya are deficient in nitrogen. Application of phosphorus at rates of 10 and $20 \mathrm{~kg} \mathrm{P} \mathrm{ha}^{-1}$ caused 25 and 39\% increase in maize grain yield, respectively, over the no-fertilizer control. The observed greater response to nitrogen than to phosphorus is probably an indication that the former was more limiting for maize production in the region than the latter.

Table 2: Effect of soil amendment on maize grain yield

\begin{tabular}{|c|c|c|c|c|}
\hline Nutrient application rate & $\begin{array}{l}\text { Grain yield } \\
\left(\mathrm{t} \mathrm{ha}^{-1}\right)\end{array}$ & $\begin{array}{l}\text { Yield increase } \\
\left(\mathrm{t} \mathrm{ha}^{-1}\right)^{\S}\end{array}$ & $\begin{array}{l}\text { Cost of nutrient } \\
\left(\mathrm{KES} \mathrm{ha}^{-1}\right)\end{array}$ & $\begin{array}{l}\text { Returns (KES) per KES } \\
\text { spent on the nutrient }{ }^{\delta}\end{array}$ \\
\hline $60 \mathrm{~kg} \mathrm{~N} \mathrm{ha}^{-1}$ & $4.4^{\mathrm{a}}$ & 1.6 & 11,100 & 3.6 \\
\hline $30 \mathrm{~kg} \mathrm{~N} \mathrm{ha}^{-1}$ & $4.0^{b}$ & 1.2 & 5,550 & 5.4 \\
\hline $20 \mathrm{~kg} \mathrm{P} \mathrm{ha}^{-1}$ & $3.9^{b}$ & 1.1 & 7,200 & 3.8 \\
\hline $10 \mathrm{~kg} \mathrm{P} \mathrm{ha}^{-1}$ & $3.5^{\mathrm{c}}$ & 0.7 & 3,600 & 4.9 \\
\hline None (Unfertilized) & $2.8^{\mathrm{d}}$ & & 0 & \\
\hline $\mathrm{LSD}_{0.05}$ & 0.35 & & & \\
\hline
\end{tabular}

${ }^{\dagger}$ Grain yield means followed by the same letter are not significantly different $(\mathrm{P}<0.05)$.

$\S$ Difference between the realized yield and that from unfertilized plots.

${ }^{\delta}$ Based on the extra yield above that realized from unfertilized plots.

Maize costs KES 25,000 per metric ton; Phosphorus costs KES $360 \mathrm{~kg}^{-1}$; Nitrogen costs KES $185 \mathrm{~kg}^{-1}$.

A farmer choosing to invest in nitrogenous fertilizer just enough to apply at half the recommended rate of $\mathrm{N}\left(30 \mathrm{~kg} \mathrm{~N} \mathrm{ha}^{-1}\right)$ would realize $10 \%$ higher returns (KES 5.4 per shilling invested in purchased fertilizer) than one who chooses to invest in phosphatic fertilizer just enough to apply at half the recommended rate of P (KES 4.9 per shilling invested in purchased fertilizer). The former corresponds with a yield increase of $500 \mathrm{~kg}$ of maize grain above that realized with the application of $10 \mathrm{~kg} \mathrm{P} \mathrm{ha}^{-1}$. Such a yield increase is enough to provide staple food for one adult person for about two years or a ten-member family for about two months. Based on the varying costs of $\mathrm{N}$ or $\mathrm{P}$ (Table 2), the farmer would make a saving of KES 1,650 ha $\mathrm{ha}^{-1}$ by adopting half the recommended rate of $\mathrm{N}\left(30 \mathrm{~kg} \mathrm{~N} \mathrm{ha}^{-1}\right)$ instead of the full rate of $\mathrm{P}\left(20 \mathrm{mg} \mathrm{kg}^{-1}\right)$ for the same grain yield level $(4 \mathrm{t}$ 
$\left.\mathrm{ha}^{-1}\right)$. Thus, at a yield level of $4.0 \mathrm{tha}^{-1}$, farmers would get better value for their money by applying half the recommended rate of nitrogen than by applying the full rate of phosphorus. This is probably due to the fact that the extractable $\mathrm{P}$ content of the soil at the study site $\left(18 \mathrm{mg} \mathrm{kg}^{-1}\right)$ is slightly above the critical level $\left(10 \mathrm{mg} \mathrm{kg}^{-1}\right)$, thus minimizing the response to applied $\mathrm{P}$.

There was a significant interaction effect $(\mathrm{P}<0.05)$ of method of managing weed biomass and crop residue during land preparation and rates of $\mathrm{P}$ and $\mathrm{N}$ application on maize grain yield (Table 3 ). While the application of $10 \mathrm{~kg} \mathrm{P} \mathrm{ha}^{-1}$ had no effect on maize grain yield where weed biomass and crop residue had been incorporated or left on soil surface, this P rate caused 64\% yield increase where weeds had been removed. An increase in the $\mathrm{P}$ application rate from 10 to $20 \mathrm{~kg} \mathrm{ha}^{-1}$ had no effect where weeds had been incorporated into soil. However, such an increase in the rate of $\mathrm{P}$ application caused $67 \%$ and $30 \%$ yield increase where weed biomass and crop residue had been either left on the soil as surface mulch or removed from the field, respectively. The lack of response of maize to applied $\mathrm{P}$ where weed biomass and crop residue had been incorporated into soil is probably an indication that $\mathrm{P}$ was not limiting under this method of managing weed biomass and crop residue during land preparation for a subsequent crop.

Table 3: Effect of method of managing weed biomass and crop residue during land preparation and rate of $\mathrm{P}$ and $\mathrm{N}$ application on maize grain yield

\begin{tabular}{|c|c|c|c|c|c|c|}
\hline \multirow{3}{*}{$\begin{array}{l}\text { Rate of nutrient } \\
\text { application }\left(\mathrm{kg} \mathrm{ha}^{-1}\right)\end{array}$} & \multicolumn{6}{|c|}{ Method of managing weed biomass and crop residue } \\
\hline & \multicolumn{2}{|c|}{ Incorporated into soil } & \multicolumn{2}{|c|}{ Used as surface mulch } & \multicolumn{2}{|c|}{ Removed from field } \\
\hline & \multicolumn{6}{|c|}{ 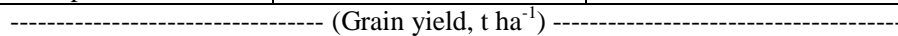 } \\
\hline Phosphorus & & Increase & & Increase & & Increase \\
\hline 0 & $2.9^{\mathrm{a}}$ & 2.9 & $2.0^{\mathrm{b}}$ & 2.0 & $1.4^{\mathrm{c}}$ & 1.4 \\
\hline 10 & $3.3^{\mathrm{a}}$ & 0.4 & $2.4^{\mathrm{b}}$ & 0.4 & $2.3^{b}$ & 0.9 \\
\hline 20 & $3.5^{\mathrm{a}}$ & 0.6 & $4.0^{\mathrm{a}}$ & 2.0 & $3.0^{\mathrm{a}}$ & 1.6 \\
\hline $\mathrm{LSD}_{0.05}$ & NS & & 0.67 & & 0.67 & \\
\hline \multicolumn{7}{|l|}{ Nitrogen } \\
\hline 0 & $2.9^{\mathrm{c}}$ & 2.9 & $2.0^{b}$ & 2.0 & $1.4^{\mathrm{b}}$ & 1.4 \\
\hline 30 & $4.0^{b}$ & 1.1 & $4.2^{\mathrm{a}}$ & 2.2 & $3.3^{\mathrm{a}}$ & 1.9 \\
\hline 60 & $5.0^{\mathrm{a}}$ & 2.1 & $4.5^{\mathrm{a}}$ & 2.5 & $3.9^{\mathrm{a}}$ & 2.5 \\
\hline $\mathrm{LSD}_{0.05}$ & 0.67 & & 0.67 & & 0.67 & \\
\hline
\end{tabular}

Means (for a given nutrient) within a column followed by the same letter are not significantly different $(\mathrm{P}<0.05)$

Maize responses to nitrogen application were observed under all methods of managing weed biomass and crop residue. However, the response to $30 \mathrm{~kg} \mathrm{~N} h a^{-1}$ was greater (yield increase of $1.9-2.2 \mathrm{t} \mathrm{ha}^{-1}$ ) when weed biomass and crop residue were either removed from the field or left on the surface as mulch, than when the material was incorporated into soil (yield increase of $1.1 \mathrm{t} \mathrm{ha}^{-1}$ ). This is probably an indication that $\mathrm{N}$ was more limiting in the former than in the latter case. The effect of increasing the rate of nitrogen application from 30 to $60 \mathrm{~kg} \mathrm{~N} \mathrm{ha}^{-1}$ was also dependent on the method of managing weed biomass and crop residue at the time of land preparation. While this increase in the rate of $\mathrm{N}$ application led to $25 \%$ increase in maize grain yield with incorporation of weed biomass and crop residue, it had no effect where weed biomass and crop residue were either left on the soil surface as mulch or removed from the field. The yield gain realized when weed biomass and crop residue were incorporated was probably caused by the combined effect of the added fertilizer $\mathrm{N}$ and nutrients released through mineralization of the weed biomass and crop residue. The laboratory analysis results showed that, on average, weed biomass contained $21 \mathrm{~kg} \mathrm{~N} \mathrm{ha}^{-1}, 2 \mathrm{~kg} \mathrm{P} \mathrm{ha}^{-1}$ and $8 \mathrm{~kg} \mathrm{~K} \mathrm{ha}^{-1}$. These results gave an indication of the potential of weed biomass as a source of nitrogen.

Residue incorporation is known to cause significant increase in microbial population in the soil (Davari et al., 2012), whose activity drives the mineralization process. Pandiaraj et al. (2015) have reported that improved crop residue management, combined with application of fertilizer $\mathrm{N}$ greatly improves the $\mathrm{N}$ economy of cereal cropping systems and enhances crop productivity in soils with a low N content. Saha (2015) also observed significant increase in fertilizer- $\mathrm{N}$ use efficiency in maize when fertilizer $\mathrm{N}$ was applied following green manure legume incorporation. The results also showed that, while the annual food requirement of an average household ( $2.7 \mathrm{t}$ maize grain) could be easily satisfied by growing maize after weed biomass and crop residue incorporation alone (to obtain at least $2.9 \mathrm{t}_{\text {grain ha }}{ }^{-1}$ ), it would be necessary to apply $20 \mathrm{~kg} \mathrm{P} \mathrm{ha}^{-1}$ or at least $30 \mathrm{~kg} \mathrm{~N} \mathrm{ha}^{-1}$ in order to satisfy the food requirement when weed biomass and crop residue are removed from the farm. Similarly, application rates of $20 \mathrm{~kg} \mathrm{Pha}^{-1}$ or $30 \mathrm{~kg} \mathrm{~N} \mathrm{ha}^{-1}$ would be required in order to satisfy the annual grain requirement of a ten-member household when maize is grown with weed biomass and crop residue used as mulch. These results indicate that subsistence farmers could easily meet their annual requirement of their staple food by growing maize following the incorporation of weed biomass and crop residue. 
Table 4 shows that farmers who cannot afford fertilizer would be better off either incorporating weed biomass and crop residue or using the material as mulch than removing it from the farm. However, incorporation of weed biomass and crop residue or their use as surface mulch alone would not sustain maize production in coastal Kenya since there would be minimal replenishment of nutrients in the soil. In the long run, higher amounts of nutrients would be removed through plant uptake than those returned into the soil through the decomposition of weed biomass and crop residue. It would therefore be necessary to supplement the contribution of weed biomass and crop residue with fertilizer nutrients. When both labour and fertilizer are taken into consideration, the results of this study showed that farmers would get the highest total returns to their investment in the two inputs (KES 4.2 for every shilling spent on labour and fertilizer) by spreading the weed biomass and crop residue on the soil surface and applying $30 \mathrm{~kg} \mathrm{~N}^{-1}$ to their maize crops. This is similar to the results of an earlier study conducted in coastal Kenya by Saha and Muli (2002), who recommended the supplementation of legume green manure with $30 \mathrm{~kg} \mathrm{~N} \mathrm{ha}^{-1}$ for maize production in the region.

Table 4: Effect of method of managing weed biomass and crop residue and rate of $\mathrm{P}$ and $\mathrm{N}$ application on the total returns to extra investment in fertilizer and/or labour

\begin{tabular}{|c|c|c|c|}
\hline \multirow{2}{*}{$\begin{array}{l}\text { Rate of nutrient application } \\
\left(\mathrm{kg} \mathrm{ha}^{-1}\right)\end{array}$} & \multicolumn{3}{|c|}{ Method of managing weed biomass and crop residue } \\
\hline & Incorporated into soil & Used as surface mulch & Removed from field \\
\hline & \multicolumn{3}{|c|}{-------- (Returns (KES) per shilling spent on fertilizer and/or labour) --- } \\
\hline \multicolumn{4}{|l|}{ Phosphorus } \\
\hline 0 & $7.3^{\dagger}$ & 6.6 & 2.8 \\
\hline 10 & 0.7 & 0.9 & 1.4 \\
\hline 20 & 0.9 & 3.4 & 2.0 \\
\hline \multicolumn{4}{|l|}{ Nitrogen } \\
\hline 0 & 7.3 & 6.6 & 2.8 \\
\hline 30 & 1.8 & 4.2 & 2.6 \\
\hline 60 & 2.5 & 3.3 & 2.6 \\
\hline
\end{tabular}

${ }^{\dagger}$ Based on the corresponding yield increases shown on Table 3, and the prices of maize and fertilizers shown on Tables 1 and 2.

In addition to the fertilizer $\mathrm{N}$, it would be necessary to also apply phosphorus in order to replenish the $\mathrm{P}$ removed through plant uptake. The application of both $\mathrm{N}$ and $\mathrm{P}$ may be achieved by applying Diammonium phosphate (DAP) as basal fertilizer, followed by a topdress of Calcium Ammonium Nitrate (CAN). Application of $\mathrm{P}$ at the rate of $10 \mathrm{~kg} \mathrm{P} \mathrm{ha}^{-1}$ will require $50 \mathrm{~kg}$ DAP, which will cost the farmer KES 3,600. Since DAP contains $18 \% \mathrm{~N}$, the farmer will be applying $9 \mathrm{~kg} \mathrm{~N}^{-1}$ in addition to the $10 \mathrm{~kg} \mathrm{P}^{-1}$. Therefore, $21 \mathrm{~kg} \mathrm{~N}$ will be required as topdress to complete the nitrogen application rate of $30 \mathrm{~kg} \mathrm{~N} \mathrm{ha}^{-1}$. This amount of $\mathrm{N}$ may be supplied by $81 \mathrm{~kg}$ CAN $(26 \% \mathrm{~N}$ ). The total cost of fertilizer inputs per hectare will be KES 3,600 (for $10 \mathrm{~kg} \mathrm{P}$ and $9 \mathrm{~kg} \mathrm{~N}$ ) plus KES 3,885 (for $21 \mathrm{~kg} \mathrm{~N}$ ). The cost for labour needed to spread weed biomass and crop residue over the soil will be KES 7,600 (i.e. 38 person days, each costing KES 200). Assuming additive effects of $\mathrm{N}$ and $\mathrm{P}$, the estimated increase in maize yield is $2.6 \mathrm{t} \mathrm{ha}^{-1}$ (Table 3). Therefore, the expected returns to total investment in fertilizer nutrient and labour for managing weed biomass and crop residue as calculated using equation 3 would be KES 4.3 for every shilling spent on labour and fertilizer. This is similar to the returns achieved by spreading the weed biomass and crop residue on the soil surface and applying nitrogen alone to maize, at the rate of $30 \mathrm{~kg} \mathrm{~N} \mathrm{ha}^{-1}$ (KES 4.2 for every shilling spent on labour and fertilizer).

When a farmer uses a tractor to prepare land, most of the weed biomass and crop residue are incorporated into soil. The farmer would therefore save KES $3,750 \mathrm{ha}^{-1}$ by using a tractor instead of incorporating the material by hand at a cost of KES $10,000 \mathrm{ha}^{-1}$ (i.e. 50 person days at KES 200 per person day). Such a saving is enough to enable the farmer purchase one 50-kg bag of DAP to supply $10 \mathrm{~kg} \mathrm{P}^{-1}$ and $9 \mathrm{~kg} \mathrm{~N}$ $\mathrm{ha}^{-1}$. If the farmer were to apply $\mathrm{P}$ and $\mathrm{N}$ at the rates of $10 \mathrm{~kg} \mathrm{P} \mathrm{ha}^{-1}$ and $30 \mathrm{~kg} \mathrm{~N} \mathrm{ha}^{-1}$, the total cost of fertilizer input would be KES 7,485 ha ${ }^{-1}$. Assuming additive effects of $\mathrm{N}$ and $\mathrm{P}$, the estimated increase in maize yield is $1.5 \mathrm{t} \mathrm{ha}^{-1}$ (Table 3). Therefore, the expected returns to total investment in fertilizer nutrient and tractor hire for incorporating weed biomass and crop residue as calculated using equation 3 would be KES 2.7 for every shilling spent on labour and fertilizer. Although the rate of $60 \mathrm{~kg} \mathrm{~N}^{-1}{ }^{-1}$ gave higher maize grain yield $\left(5 \mathrm{tha}^{-1}\right)$ than that realized with $30 \mathrm{~kg} \mathrm{~N} \mathrm{ha}^{-1}\left(4 \mathrm{t} \mathrm{ha}^{-1}\right)$ with incorporation (Table 3), the former rate would not be practicable because of the low economic base of the smallholder farmers of coastal Kenya.

\section{Conclusion}

The results of this study have shown that farmers can achieve the same yield level (at least $4 \mathrm{t} \mathrm{ha}^{-1}$ ) if they incorporated weed biomass and crop residue into the soil or spread the material over the soil as mulch, followed by the application of $10 \mathrm{~kg} \mathrm{Pha}^{-1}$ and $30 \mathrm{~kg} \mathrm{~N} \mathrm{ha}^{-1}$. By utilizing the weed biomass and crop residue on 
their farms, farmers would be able to improve their returns to money spent on fertilizer and tractor hire or labour while also minimizing the requirement for fertilizer-P. It is therefore necessary that farmers are educated on the kind of losses they incur (an average of $23 \%$ yield decline) by removing weed biomass and crop residue from their farms before tilling the land. From the results of this study, it can be recommended that smallholder farmers in coastal Kenya adopt the use of weed biomass and crop residue by either incorporating the material using a tractor plough or preparing land by hand and spreading the material over the soil as mulch, followed by the application of phosphorus and nitrogen at half the recommended rates $\left(10 \mathrm{~kg} \mathrm{P} \mathrm{ha}^{-1}\right.$ and $\left.30 \mathrm{~kg} \mathrm{~N} \mathrm{ha}{ }^{-1}\right)$ for maize production.

\section{References}

[1] M. Al-Kaisi, and J. Guzman, Effect of maize residue removal on soil quality and greenhouse gas emissions in Iowa, Agrociencia Uruguay, 16(3), 2012, 20-28.

[2] M.R. Davari, S.N. Sharma and M. Mirzakhani, Effect of cropping systems and crop residue incorporation on production and properties of soil in an organic agroecosystem, Biological Agriculture \& Horticulture, 28(3), 2012, $206-222$.

[3] J.G. Mureithi, P.M. Mwaura and C.O. Nekesa, Introduction of legume cover crops to smallholder farms in Gatanga, Central Kenya, in J.G. Mureithi, C.K.K. Gachene, F.N. Muyekho, M. Onyango, L. Mose and O. Magenya (Ed.), Participatory technology development for soil management by smallholder farmers in Kenya, Proceedings of the $2^{\text {nd }}$ Scientific Conference of the Soil Management and Legume Research Network Projects (Mombasa, Kenya, 2002) 134-164.

[4] J.G. Mureithi, H.M. Saha, M.N. Njunie, G.M. Kamau, T.L. Munga, A. Blokland, F.K. Muniu, M.B. Muli, A. Ramadhan and E. Wekesa. An appraisal of methods used by farmers to manage soil fertility in coastal Kenya, Proc. 15th Conference of the Soil Science Society of East Africa, Nanyuki, Kenya, 2000, 371-386.

[5] J.R. Okalebo, K.W. Gathua and P.L. Woomer, Laboratory methods of soil and plant analysis: A working manual (TSBF-CIAT and SACRED Africa, Kenya: Nairobi, 2002).

[6] S.W. Omamo, M. Walsh and Gem. Argwings-Kodhek, Diversity and dynamics in Kenyan agriculture: The challenge for agricultural research policy and management, in C.G. Ndiritu, J.K. Lynam and A.N. Mbabu (Ed.), Transformation of agricultural research systems in Africa: Lessons from Kenya, (East Lansing, Michigan, Michigan State University Press, 2004) 45-58.

[7] C.A. Palm, R.J.K. Myers, S.M. Nandwa, Combined use of organic and inorganic nutrient sources for soil fertility maintenance and replenishment, SSSA Special Publication 51. Soil Science Society of America, Madison, WI, USA, 1997, $193-217$.

[8] T. Pandiaraj, S. Selvaraj, and N. Ramu, Effects of crop residue management and nitrogen fertilizer on soil nitrogen and carbon content and productivity of wheat (Triticum aestivum L.) in two cropping systems, Journal of Agricultural Science and Technology, 17, 2015, 249-260.

[9] H.M. Saha, and M.B. Muli, Effects of combining green manure legumes, farmyard manure and inorganic fertilizer on maize yield in coastal Kenya, in J.G. Mureithi, C.K.K. Gachene, F.N. Muyekho, M. Onyango, L. Mose and O. Magenya (Ed.), Participatory technology development for soil management by smallholder farmers in Kenya, Proceedings of the $2^{\text {nd }}$ Scientific Conference of the Soil Management and Legume Research Network Projects (Mombasa, Kenya, 2002) 103-113.

[10] H.M. Saha, L.S. Wamocho, F.K. Lenga, and J.G. Mureithi, Effect of legume plant density and intercropping on performance of maize and mucuna, East African Agricultural and Forestry Journal, 74(1), 2008, 1-9.

[11] H. Saha, Resource use under maize-green manure legume intercropping systems (LAP Lambert Academic Publishing, Germany: Deutschland, 2015).

[12] SAS Institute, SAS proprietary software release 8.2 (SAS Inst., NC: Cary, 1999).

[13] J.H.J. Spiertz, Nitrogen, sustainable agriculture and food security. A review, Agronomy for Sustainable Development, 30(1), 2010, 43-55

[14] E. Wekesa, W. Mwangi, H. Verkuijl, K. Danda, and H. Degroote, Adoption of maize production technologies in the coastal lowlands of Kenya (CIMMYT, Mexico: D.F., 2003). 